\title{
Dentistry in the Dominican Republic
}

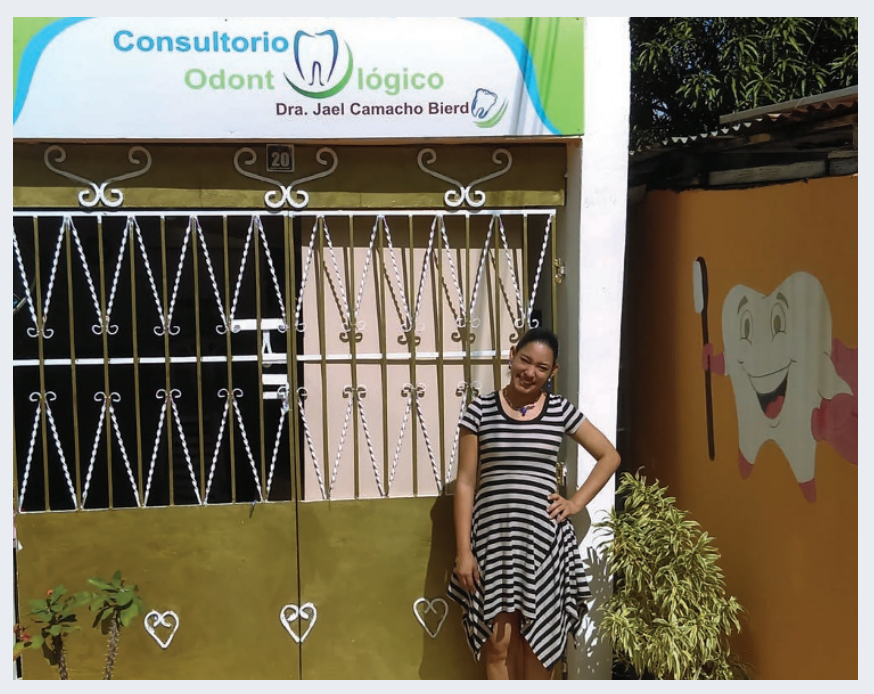

$\mathrm{D}$ espite recent concerns in the UK about access to a career in dentistry in light of increasing student debt, increasing tuition fees, and the threat to student NHS Bursaries, we can still aspire to be a fairly diverse profession. There are parts of the world where access to university remains an impossible dream for many people.

Over 45,000 students study at the University of Santo Domingo in the Dominican Republic, the oldest university in the Americas. However, large parts of the population have little chance of studying there, as is the case in many developing countries. These same communities suffer from a lack of affordable dental care provision. Organisations like Compassion International are changing this*.

In 2009, via Compassion International, my wife and I heard about an undergraduate dental student in the Dominican Republic who was about to start her studies and needed sponsorship support. This is how my family first got to know Jael Camacho Bierd. Jael started her dentistry degree in September 2009. Alongside her

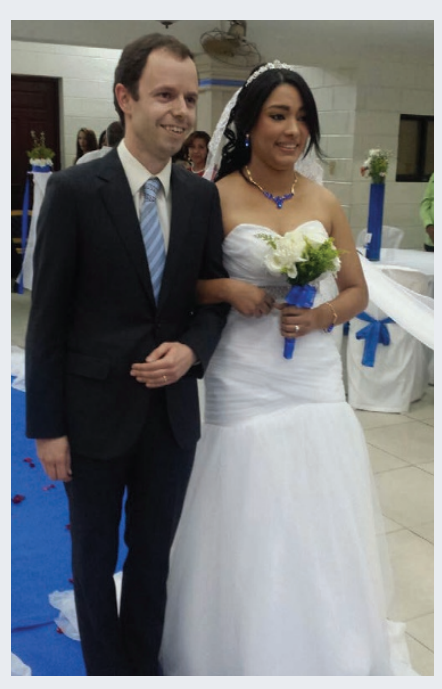
undergraduate studies she also completed the Compassion Leadership Development Programme (LDP) and English language studies.

Over the years during Jael's undergraduate studies she has been in regular written contact, including updates regarding her studies and career plans. For her final dissertation she undertook some research about increasing the ability and facilities to deal with medical emergencies in dental practice, and was surprised with the high standards already in place in the UK. Our medical emergencies guidance from BNF and Resuscitation Council (UK) gave her some useful reference material, and Google

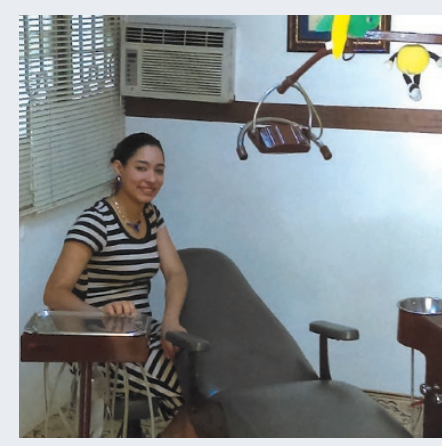
Translate let me make sense of her dissertation in Spanish. We have been very encouraged to see Jael progress with her degree and it has been interesting to find out about dental studies and dentistry in another country.

Jael contacted us last year to tell us that she was getting married and invited our family to attend the wedding. Her fiancé Querube, a doctor in an Emergency Department at a hospital in Santo Domingo, also studied medicine through the Compassion LDP scheme. On Boxing Day 2016 my wife and I flew to the Dominican Republic, with our two daughters aged eight and four years. We were met by Jael at the airport, and during our visit we met Jael's family and friends. We stayed in the city, as well as getting the opportunity to see some of the countryside and Jael's community.

Part of our alternative Caribbean Christmas break was spent helping with final wedding preparations. Over the years, Jael had talked about us being like extended family to her, and she asked if I would walk her down the aisle on her wedding day. Our eight-yearold daughter was also involved as ring bearer during the ceremony. It was a very enjoyable visit, particularly to be there to celebrate Jael's wedding.

During our visit we also got to find out more about Jael's plans for work. She has always wanted to work within the heart of her local community, providing much needed access to dental treatment. Since graduating in 2015 we have been part of assisting Jael to set up her own dental office in her mother's house. However, she has been unable to use this facility so far as there are lengthy delays acquiring the necessary Exequatur paperwork after graduation in the Dominican Republic. In the meantime, Jael has been visiting local schools and providing very necessary oral health information to students and children. She hopes at some point in the future to undertake further study in paediatric dentistry.

When asked about her plans for the future Jael said 'I am planning to help as many people as I can, because in this country it is not easy to get dental services to poor people'. I think that is an excellent way to use her dental training, and something which helps to put into perspective what we do in the UK in our daily work within the NHS or private practice.

By Paul Blaylock, BDA PEC member \& Chair of Students Committee

${ }^{*}$ Compassion International run a Leadership Development Programme which gives promising young people in developing countries support, both financial and academic. Through linking up with overseas sponsors, the aim is to provide leaders of the future who can through higher education go on to influence families, communities, churches and nations. www.compassion.co.uk 